\title{
Tiger (Panthera tigris) scent DNA: a valuable conservation tool for individual identification and population monitoring
}

\author{
Anthony Caragiulo $^{1} \cdot$ Rob Stuart Alexander Pickles ${ }^{2,3} \cdot$ Joseph Alexander Smith $^{2,4}$. \\ Olutolani Smith ${ }^{2} \cdot$ John Goodrich $^{2} \cdot$ George Amato $^{1}$
}

Received: 31 October 2014/Accepted: 8 June 2015/Published online: 13 June 2015

(c) The Author(s) 2015. This article is published with open access at Springerlink.com

\begin{abstract}
Genetic monitoring of tiger source populations is a conservation priority, yet due to low sample sizes and poor DNA quality, scat DNA has failed to produce the powerful studies needed to inform management decisions in humid, tropical landscapes. Here, we report the first successful extraction of DNA from tiger scent marks, a hitherto neglected genetic resource. We show that tiger scent DNA quality is equal or superior to scat DNA, and as scent marks are encountered 2-8 times more frequently in the wild than scats, they constitute an important genetic resource for monitoring populations and individuals.
\end{abstract}

Keywords Panthera tigris - Non-invasive sampling · Scent sprays $\cdot$ Individual identification

Fewer than 3500 tigers (Panthera tigris) remain in the wild, occupying $<7 \%$ of their historical range despite intense conservation efforts. Seventy percent of these tigers occur

Electronic supplementary material The online version of this article (doi:10.1007/s12686-015-0476-9) contains supplementary material, which is available to authorized users.

Anthony Caragiulo

acaragiulo@amnh.org

1 Sackler Institute for Comparative Genomics, American Museum of Natural History, 79th Street at Central Park West, New York, NY 10024, USA

2 Panthera, 8 West 40th Street, 18th Floor, New York, NY 10018, USA

3 Department of Biology, Trent University, Peterborough, ON K9J 7B8, Canada

4 Wildlife Conservation Research Unit, Department of Zoology, University of Oxford, Recanati-Kaplan Centre, Tubney House, Abingdon Rd, Tubney, UK within 42 source populations covering $<0.5 \%$ of their historic range (Walston et al. 2010). Evaluating the success of conservation interventions requires rigorous monitoring of tiger densities and connectivity among populations. DNA analysis from scats has traditionally been used for genetic monitoring of wild tigers, but scat detection rates are generally low, particularly in humid, tropical environments, which limits their utility as a genetic resource (Smith 2012; A. Johnson, pers. comm.). Scent marks by contrast, constitute an untapped genetic resource, as they are more frequently deposited and have much higher detection rates than scats (Smith et al. 1989; Yudakov and Nikolaev 2012). Surveying over $664.4 \mathrm{~km}$ in the Russian Far East revealed scent spray to scat deposition ratios of 319:38 for males, and 109:46 for females (Yudakov and Nikolaev 2012). In Chitwan National Park, a subtropical forest in Nepal, the detection ratio was 612:28 (Smith et al. 1989) and in Tambling Wildlife Nature Conservation, a dense lowland tropical forest reserve in southern Sumatra, the detection ratio was 53:15 over 9 months of patrol activity (unpublished data). Tigers spray on trees and overhanging leaves along territory boundaries as a means of olfactory communication (Fig. 1). To boost the effectiveness of genetic monitoring of tigers, we examined the potential for DNA amplification from tiger scent marks for individual identification and gender determination.

Scent DNA samples were collected from three captive tigers ( 2 males, 1 female) in southern Ontario in November 2013 and June 2014. Two to four samples were collected per individual and estimated time between marking and sampling varied from $10 \mathrm{~min}$ to $39 \mathrm{~h}$. Scent marks were swabbed using sterile cotton buds, the swabs placed in a vial containing $500 \mu \mathrm{L}$ Buffer ASL (Qiagen) and stored at room temperature. The cotton tip was excised and placed in a sterile $2.0 \mathrm{~mL}$ tube with the initial Buffer ASL aliquot 


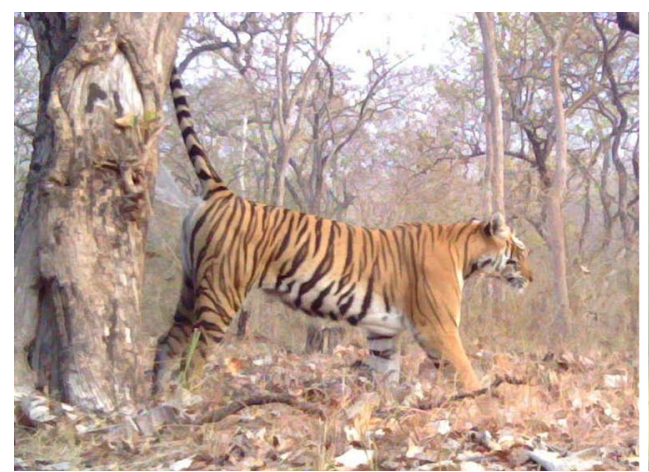

Fig. 1 Scent marks are typically $10-30 \mathrm{~cm}$ in diameter, $42 \mathrm{~cm}-$ $1.7 \mathrm{~m}$ above ground, and sprayed on trees (left, Sanjay Gubbi/NCF/ Panthera) or underneath overhanging leaves such as wild ginger

Table 1 Percentage of successful independent PCR, and allelic dropout and false allele rates using DNA from captive tiger scent sprays

\begin{tabular}{llll}
\hline Locus & \% Positive PCR & Allelic dropout & False allele \\
\hline FCA100 & 83 & 0.136 & 0.000 \\
FCA124 & 83 & 0.209 & 0.000 \\
FCA126 & 83 & 0.000 & 0.056 \\
FCA212 & 83 & 0.333 & 0.000 \\
FCA229 & 83 & 0.000 & 0.064 \\
Mean & 83 & 0.136 & 0.024 \\
\hline
\end{tabular}

Allelic dropout and false allele rates are calculated as mean values over total number of successful PCRs

and $15 \mu \mathrm{L}$ Proteinase K (Qiagen). Samples were incubated at $65{ }^{\circ} \mathrm{C}$ for $2 \mathrm{~h}$, after which an additional $15 \mu \mathrm{L}$ of Proteinase $\mathrm{K}$ was added prior to incubation at $37{ }^{\circ} \mathrm{C}$ for $12 \mathrm{~h}$. $500 \mu \mathrm{L}$ Buffer AL (Qiagen) was added and the sample incubated at $65{ }^{\circ} \mathrm{C}$ for $10 \mathrm{~min}$, after which $500 \mu \mathrm{L}$ of cold $100 \%$ ethanol was added and the sample incubated at $4{ }^{\circ} \mathrm{C}$ for $1 \mathrm{~h}$. The remainder of the extraction process followed the suggested QIAGEN DNeasy Blood \& Tissue Kit protocol, except DNA was eluted using $50 \mu \mathrm{L}$ Buffer AE heated to $70{ }^{\circ} \mathrm{C}$ and left to incubate on the spin column membrane for $30 \mathrm{~min}$ prior to centrifugation. DNA was stored at $-20{ }^{\circ} \mathrm{C}$ until analyzed.

Species identification was tested by amplifying a $110 \mathrm{bp}$ fragment of the cytochrome oxidase $b$ mitochondrial gene using primers H15149 (Kocher et al. 1989) and Farrel-R (Farrell et al. 2000). Sequencing followed Caragiulo et al. (2014). Five microsatellite loci in two multiplex groups (Menotti-Raymond et al. 1999) were used for individual

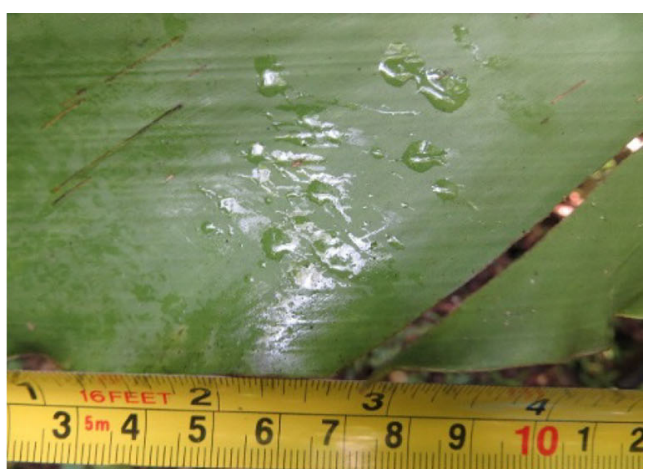

(right, Rob Pickles/Panthera). Fresh sprays are commonly detected in the wild due to their unique aroma

identification (Table S1). Gender was determined using fluorescently labeled primers for the amelogenin region of the sex chromosomes (Pilgrim et al. 2005). Each gender typing reaction consisted of $3.50 \mu \mathrm{L}$ of QIAGEN MasterMix, $0.70 \mu \mathrm{L}$ of Q-solution, $0.20 \mu \mathrm{L}$ of $10 \mu \mathrm{M}$ amelogenin primers (Pilgrim et al. 2005), $0.20 \mu \mathrm{L}$ of DNase-free water, and $2.0 \mu \mathrm{L}$ of DNA template. Both microsatellite and gender-typing PCRs were done in triplicate using the multiple tubes approach (Taberlet et al. 1996). All PCRs were prepared and analyzed as per Caragiulo et al. (2015). Genotyping error rates were estimated using GIMLET version 1.3.2 (Valière 2002).

All cytochrome oxidase $b$ sequences were successfully identified as tiger. All samples yielded reliable consensus genotypes, except DNA from a single swab that failed completely in all three replicates. Gender was correctly confirmed for all individuals. The PCR success rate (Table 1) and genotyping error rates (Table 2) are comparable to tiger genetic studies using scat and fall below the thresholds described by Smith and Wang (2014) for effective estimation of genetic variation and population subdivision. Comparable error rates are expected in tiger habitat with similar temperature ranges to those experienced during collection. Although error rates in the tropics may be higher, overall collection of scent DNA samples in tiger genetic studies in addition to scats, would significantly increase overall sample sizes, facilitating resolving individual genotypes and enabling more powerful genetic studies to take place. Since genetic connectivity is key to the long-term viability of the remaining 42 source populations, increased and high quality monitoring, using novel techniques such as the one presented here, are critical for the effective conservation management of wild tigers. 
Table 2 Comparison of PCR success and error rates (mean across loci) for tiger sprays versus tiger scats

\begin{tabular}{|c|c|c|c|c|c|c|c|}
\hline Study & Location & $\begin{array}{l}\text { Sample } \\
\text { Size }\end{array}$ & $\begin{array}{l}\text { Sample } \\
\text { type }\end{array}$ & $\begin{array}{l}\text { Collection } \\
\text { environment }\end{array}$ & $\begin{array}{l}\% \text { Positive } \\
\text { PCR }\end{array}$ & $\begin{array}{l}\text { Allelic } \\
\text { dropout }\end{array}$ & $\begin{array}{l}\text { False } \\
\text { allele }\end{array}$ \\
\hline This study & - & 14 & Spray & Captive & 83 & 0.136 & 0.024 \\
\hline Unpublished data & Lao PDR & 21 & Scat & Mixed forest & 69 & 0.285 & 0.004 \\
\hline Smith (2012) & Sumatra & 27 & Scat & Tropical rainforest & 54 & 0.340 & 0.050 \\
\hline Mondol et al. (2009) & Northern India & 50 & Scat & Dry deciduous & 90 & 0.0067 & 0.000 \\
\hline Reddy et al. (2012) & Northern India & 103 & Scat & Tropical dry forest & 92 & 0.037 & - \\
\hline Gour et al. (2013) & Central India & 75 & Scat & Mixed forest & 82.5 & 0.047 & - \\
\hline Sharma et al. (2013) & Central India & 463 & Scat & Mixed forest & - & 0.011 & 0.006 \\
\hline Bhagavatula and Singh (2006) & Southern India & 28 & Scat & Unknown & 60 & 0.3765 & 0.0235 \\
\hline
\end{tabular}

Acknowledgments We thank Peter Klose at Jungle Cat World, and Dr. Wendy Korver and Michael Hackenberger at Bowmanville Zoo for providing tiger scent marks. We thank Tambling Wildlife Nature Conservation, and the Ministry of Forestry for the Republic of Indonesia for supporting related fieldwork.

Open Access This article is distributed under the terms of the Creative Commons Attribution 4.0 International License (http://creativecommons.org/licenses/by/4.0/), which permits unrestricted use, distribution, and reproduction in any medium, provided you give appropriate credit to the original author(s) and the source, provide a link to the Creative Commons license, and indicate if changes were made.

\section{References}

Bhagavatula J, Singh L (2006) Genotyping faecal samples of Bengal tiger Panthera tigris tigris for population estimation: a pilot study. BMC Genet 7:1-12

Caragiulo A, Dias-Freedman I, Clark JA, Rabinowitz S, Amato G (2014) Mitochondrial DNA sequence variation and phylogeography of Neotropic pumas (Puma concolor). Mitochondr DNA 25:304-312

Caragiulo A, Kang Y, Rabinowitz S, Dias-Freedman I, Loss S, Zhou X-W, Bao W-D, Amato G (2015) Presence of the Endangered Amur tiger Panthera tigris altaica in Jilin Province, China, detected using non-invasive genetic techniques. Oryx FirstView. doi: $10.1017 / \mathrm{S} 0030605314000817$

Farrell L, Roman J, Sunquist M (2000) Dietary separation of sympatric carnivores identified by molecular analysis of scats. Mol Ecol 9:1583-1590

Gour DS, Bhagavatula J, Bhavanishankar M, Reddy PA, Gupta JA, Sarkar MS, Hussain SM, Harika S, Gulia R, Shivaji S (2013) Philopatry and dispersal patterns in tiger (Panthera tigris). PLoS One 8:e66956. doi:10.1371/journal.pone.0066956

Kocher TD, Thomas WK, Meyer A, Edwards SV, Pääbo S, Villablanca FX (1989) Dynamics of mitochondrial DNA evolution in animals: amplification and sequencing with conserved primers. Proc Natl Acad Sci USA 86:6196-6200
Menotti-Raymond M, David V, Lyons L, Schäffer A, Tomlin J, Hutton M, O'Brien S (1999) A genetic linkage map of microsatellites in the domestic cat (Felis catus). Genomics 57:9-23

Mondol S, Karanth KU, Kumar NS, Gopalaswamy AM, Andheria A, Ramakrishnan U (2009) Evaluation of non-invasive genetic sampling methods for estimating tiger population size. Biol Conserv 142:2350-2360

Pilgrim K, McKelvey K, Riddle A, Schwartz M (2005) Felid sex identification based on noninvasive genetic samples. Mol Ecol Notes 5:60-61

Reddy PA, Kumaraguru A, Bhagavatula J, Gour DS, Bhavanishankar M, Shekhar Sarkar M, Harika K, Hussain SM, Shivaji S (2012) Tiger presence in a hitherto unsurveyed jungle of India-the Sathyamangalam forests. Conserv Genet 13:779-787

Sharma S, Dutta T, Maldonado JE, Wood TC, Panwar HS, Seidensticker J (2013) Spatial genetic analysis reveals high connectivity of tiger (Panthera tigris) populations in the Satpura-Maikal landscape of Central India. Ecol Evol 3:48-60

Smith O (2012) Population genetics and structure of the Sumatran tiger. Imperial College, London

Smith O, Wang J (2014) When can noninvasive samples provide sufficient information in conservation genetics studies? Mol Ecol Resour 14:1011-1023

Smith JLD, McDougal C, Miquelle D (1989) Scent marking in freeranging tigers, Panthera tigris. Anim Behav 37:1-10

Taberlet P, Griffin S, Goossens B, Questiau S, Manceau V, Escaravage N, Waits LP, Bouvet J (1996) Reliable genotyping of samples with very low DNA quantities using PCR. Nucleic Acids Res 24:3189-3194

Valière N (2002) GIMLET: a computer program for analysing genetic individual identification data. Mol Ecol Notes 2:377-379

Walston J, Robinson JG, Bennett EL, Breitenmoser U, da Fonseca GAB, Goodrich J, Gumal M, Hunter L, Johnson A, Karanth KU (2010) Bringing the tiger back from the brink - the six percent solution. PLoS Biol 8:e1000485

Yudakov A, Nikolaev I (2012) Winter ecology of the Amur tiger based upon observations in the west-central Sikhote-Alin Mountains, 1970-1973, 1996-2010, 2nd revised edn. Wildlife Conservation Society, Dalnauka, Vladivostok 